\title{
RESISTÊNCIAS CRÍTICAS NO PALCO VERDE DE MÁRCIO SOUZA
}

\author{
CRITICAL RESISTANCES ON MÁRCIO SOUZA'S GREEN STAGE
}

\author{
Walace Rodrigues ${ }^{1}$ \\ Antônio Coutinho Soares Filho ${ }^{2}$
}

\section{RESUMO}

Este artigo consiste numa apresentação panorâmica do teatro de Márcio Souza, tendo em vista a relevância de sua obra para a literatura dramática brasileira. O escritor manauara, hábil no manejo da linguagem, imprime ao seu teatro um forte teor contestatório em relação aos desmandos políticos da nação e, em especial, aos que tocam diretamente a Amazônia. Desse modo, o estudo tem como objetivo principal traçar um painel crítico do teatro souziano, demonstrando a articulação de suas peças no conjunto de sua obra ficcional, como também sua contribuição para o teatro brasileiro. O percurso metodológico parte da relação entre a literatura souziana e a Amazônia, passando pela caracterização de seu teatro e chegando a uma exposição sumária de suas onze peças. Como resultados, vemos que num país de excluídos, onde resquícios totalitários insistem em medrar, o estudo do teatro de Márcio Souza mostra-se pertinente, pois entre seus pontos fulcrais estão a denúncia e a resistência críticas.

Palavras-chave: Amazônia; Teatro; Márcio Souza.

\section{ABSTRACT}

This paper consists of a panoramic presentation of Márcio Souza's theater style, considering his work's relevance to Brazilian dramatic literature. The Amazon-born writer with superb language skills gives his theater a strong contentious content concerning the nation's political misdeeds and, in particular, to those that directly affect the Amazon. The study's main objective is to draw a critical panel of the Souzian theater, demonstrating the articulation of its plays, its fictional work set, and its contribution to the Brazilian theater. The methodological path starts at the relationship between Souzian literature and the Amazon, passing through the characterization of its theater and arriving at a summary exhibition of its eleven plays. As a result, we see that in a country of the excluded, where totalitarian remnants insist on thriving, the study of Márcio Souza's theater proves to be pertinent because among its central points are the critical denunciation and resistance.

Keywords: Amazon; Theater; Márcio Souza.

\footnotetext{
${ }^{1}$ Atualmente é Professor Adjunto da Universidade Federal do Tocantins (UFT). Docente do Programa de PósGraduação em Demandas Populares e Dinâmicas Regionais (PPGDire) e da Pós-Graduação em Ensino de Língua e Literatura (PPGL). Pós-Doutor pela Universidade de Brasília - UnB/POSLIT. e-mail: walacewalace@hotmail.com

${ }^{2}$ Atualmente é Doutorando do Programa de Pós-Graduação em Letras: Ensino de Língua e Literatura - PPGL, da Universidade Federal do Tocantins, Campus Araguaína. Professor da Universidade Estadual da Região Tocantins do Maranhão (UEMASUL). e-mail: coutinhofilho70@gmail.com
} 
Viver é ser como os

pássaros ensandecidos

no fragor

da tempestade.

(SOUZA, 1997a, p. 78)

\section{AFLUENTES DE SOUZA COMO INTRODUÇÃO}

A Amazônia, com sua complexa configuração social, histórica, cultural e humana, ocupa lugar central na obra de Márcio Souza. O escritor, nascido em Manaus, percorre diversas trilhas inventivas, mediante as quais problematiza a região, os seres que a povoam e as relações de poder que nela se estabelecem. Embora parta de uma realidade específica, a agudeza de seu olhar não the permite circunscrever-se ao âmbito regional, pelo contrário, sua obra insere a Amazônia num debate macroestrutural, mostrando, com isso, não obstante as particularidades locais, tratar-se de um único país com uma realidade múltipla e complexa. $\mathrm{O}$ autor, cosmopolita e dinâmico, possui uma visão conjuntural, fato que o impede de insular-se nos infindáveis caminhos da floresta.

Sem abrir mão do feitio artístico que o texto literário comporta, o escritor manauara assume uma postura que, longe de proselitismos, pode-se chamar de combativa. Corroboram, para tanto, um profundo conhecimento da realidade amazônica, a compreensão do papel social do artista, como também a crença no poder contradiscursivo da literatura. Assim, sua obra ressalta a pluralidade cultural amazonense e a rica mitologia indígena, mas sem esquecer de trazer à tona a barbárie da colonização, o extermínio e a marginalização dos povos nativos, a ganância desenfreada de poderosas potências mundiais, a exploração irresponsável dos recursos naturais, bem como os desmandos políticos da nação, em particular, os que atingem diretamente a Amazônia.

Em consonância com os vários caminhos discursivos que percorre, Márcio Souza exercita a palavra em gêneros diversos, incluindo nesse rol romance, conto, teatro, ensaio, crítica literária, reportagem e cinema. Sua obra, seja no âmbito ficcional ou não, constrói-se a partir da consciência das disparidades sociais que permeiam o país oriundas, sobretudo, de um processo colonizador brutal e da voragem capitalista. Desse modo, o olhar crítico e a linguagem 


\section{nevitate

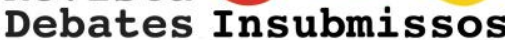

precisa lhe garantem, seja como romancista, dramaturgo, cineasta, ensaísta ou jornalista, uma obra que tem muito a dizer.

O escritor, com tinta ácida, não se intimida em expor as mazelas do país e os desmandos dos poderosos. Em acordo com essa diretiva, sua obra denuncia o vicioso ciclo de usufruto do poder que, infelizmente, insiste em perdurar, alargando cada vez mais o abismo entre dominantes e explorados. Dessa forma, a escrita souziana dá voz aos que foram, e são, silenciados ao mesmo tempo que põe em suspeição os relatos oficiais.

A diversidade de gêneros que perfaz a produção de Márcio Souza permite um amplo leque de abordagens analíticas. Se por um lado, isso vem acontecendo, sobretudo, com sua romanesca; por outro, existem muitos caminhos abertos. Dentre esses, sua dramaturgia é uma via interessante de investigação, ainda mais quando se leva em conta que a literatura dramática, de forma geral, não figura na preferência dos estudos literários. Com efeito, a poesia e a narrativa polarizam as atenções, como se pode observar, sem muita dificuldade, nos bancos de dissertações e de teses das principais universidades do país. Com isso, a literatura dramática entendendo-se esta como a escrita ficcional cuja tessitura, independente de seu teor literário, tem a representação teatral como horizonte - percorre as trilhas marginais do interesse acadêmico.

Pelas razões citadas, o presente trabalho elege o teatro de Márcio Souza como objeto de pesquisa, tendo em vista a relevância de sua obra para a literatura brasileira, em especial, por colocar em evidência a Amazônia. O manejo hábil da linguagem souziana imprime ao seu teatro um forte componente contestatório que não passa despercebido. Pelo contrário, o escritor, mediante sua veia dramática, tem muito a dizer acerca do país em geral e de sua região em particular.

Desse modo, este artigo tem como principal intuito traçar um panorama do teatro souziano, demonstrando a articulação de suas peças no conjunto de sua produção ficcional. Adicione-se a isso o interesse em contribuir com a fortuna crítica do autor, especificamente, sua dramaturgia, como também do teatro brasileiro. 


\section{Revista \\ Debates Insubmissos}

Composto de onze peças, o teatro de Souza constitui uma dramaturgia caleidoscópica com várias nuances criativas, pois o autor não se atém a um único gênero teatral. A extensão desse corpus, mesmo em face de uma apresentação sumária como esta, exige um recorte epistemológico preciso. Neste caso, o estudo incide sobre sua literatura dramatúrgica, excluindo-se, portanto, qualquer referência às montagens das peças no palco. No entanto, vale a ressalva, a dimensão espetacular desses textos não pode ser totalmente posta de lado, pois, em sua raiz, está a potência da representação. Eles podem, e devem, ser lidos - individualmente ou em conjunto - e analisados, todavia a ribalta é o seu horizonte de projeção. Se isso se aplica aos textos dramáticos em geral, no caso de Márcio Souza é mais pertinente, dado seu engajamento com o teatro amazonense à época de escrita das peças.

De seus textos teatrais, apenas dois não têm a Amazônia como cenário. Apesar disso, o autor não cai na armadilha do exótico, tendência comumente observada quando se trata do universo amazônico. Pelo oposto, ele extrai da realidade regional importantes reflexões cuja abrangência histórica, social, política e humana extrapolam o momento e o local de produção. $\mathrm{Na}$ verdade, o escritor, em inquieta busca por expressões cênicas que se coadunem com suas preocupações artístico-sociais, concebe o palco como forma de questionamento ao poder instituído. Em sintonia com essa plataforma inventiva, sua obra dramática apresenta como eixos centrais a mitologia indígena, a sátira social e a crítica política. Tais mecanismos discursivos podem ser lidos como ferramentas de resistência e de propaganda das mazelas dos deixados de lado do norte do país.

Acrescente-se ainda que as articulações míticas, satíricas e políticas do teatro de Márcio Souza aglutinam temáticas que visam à construção de um teatro popular, crítico e socialmente comprometido com a conscientização de seu público. A atitude engajada da dramaturgia souziana não significa uma adesão partidária, mas a consciência de que a arte constitui, também, um exercício de desvelamento dos mecanismos de alienação do povo. Nesse sentido, seu itinerário criativo faz o caminho contrário do que fizera, por exemplo, a dramaturgia jesuítica no período colonial. Esta, ancorada no discurso religioso contrarreformista, propunha, sobretudo na figura de José de Anchieta, a conversão do indígena por meio de um teatro 


\section{nowite

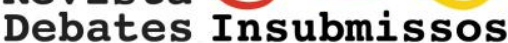

catequético e, por isso, dogmático. Conforme Bosi (2010, p. 68), "Nos autos [de Anchieta] assiste-se à dramatização de um processo que se instaura de fora para dentro da vida tribal", quer dizer, a dramatização a serviço da dominação.

Por seu turno, a obra dramática de Márcio Souza acompanha as preocupações políticas do teatro brasileiro produzido a partir da segunda metade do séc. XX. Para além da referencialidade histórica e das particularidades estéticas, Souza e seus pares - Dias Gomes, Augusto Boal, Gianfrancesco Guarnieri, Chico Buarque ${ }^{3}$, dentre outros - se abrem às inovações trazidas pela moderna dramaturgia mundial. Segundo Rosenfeld (2018a, p. 44), essas novidades "são tentativas de assimilar a nova visão do homem e do mundo à estrutura dramática e cênica; visão que acompanha ou resulta das enormes transformações sociais e técnicas, assim como das concepções científicas e filosóficas do nosso tempo." Ao mesmo tempo, há a preocupação de discutir e apresentar a realidade brasileira nos palcos, motivo pelo qual Prado (2018, p. 61) afirma que esses dramaturgos "tinham em comum a militância teatral e a posição nacionalista." Em relação a este ponto, o crítico garante:

Quanto ao lado nacionalista, todos o representavam, seja por inclinação política, seja por retratar em cena aspectos menos conhecidos ou menos explorados dramaticamente do Brasil, seja, enfim, pela simples presença em palco de suas peças, o que, em face do predomínio de repertório estrangeiro, significava sempre uma tomada de posição, se não deles, ao menos das empresas que os encenavam. Começava-se a apostar no autor brasileiro, como antes se apostara na possibilidade de se fazer espetáculos modernos entre nós (PRADO, 2018, p. 61-62).

\footnotetext{
3 Veja-se, por exemplo, que as peças de Dias Gomes O pagador de promessas (1959), A invasão (1960) e O berço do herói (1963) (as duas últimas proibidas pela censura federal) tematizam a intolerância dos poderosos, a corrupção política, a exclusão social e o mascaramento da falência institucional do país. Em Eles não usam blacktie (1958), de Gianfrancesco Guarnieri, traz-se ao palco, pela primeira vez no Brasil, uma greve operária, além do protagonismo ficar a cargo dos moradores de uma favela. O dramaturgo e diretor Augusto Boal, criador do Teatro do Oprimido, inovou o teatro brasileiro com espetáculos como Revolução na América do Sul (1957), cujo protagonista é a classe operária, e Arena conta Zumbi (1965), escrita em parceria com G. Guarnieri e com música de Edu Lobo, ao encenar a opressão e a resistência dos quilombolas de Palmares. Por sua vez, Chico Buarque teve as peças Roda viva (1967) e Calabar, o elogio da traição (1972, em parceria com Ruy Guerra) censuradas pelo regime civil-militar. A primeira é uma ferrenha crítica à sociedade consumista e aos problemas sociais, já Calabar propõe uma revisão do passado histórico ao mesmo tempo que denuncia o silenciamento perpetrado pelo Estado, enquanto Gota d'água (1975, em parceria com Paulo Pontes, liberada com cortes) apresenta as precárias condições de vida dos moradores de um conjunto habitacional no subúrbio carioca. Como se nota, esse momento do teatro nacional era uma trincheira da qual não se podia largar, o preço da desistência seria muito mais danoso que os cortes e proibições.
} 


\section{Revista \\ Debates Insubmissos}

De olho na conjuntura mundial, o teatro épico de Bertold Brecht, por exemplo, de orientação marxista, é uma importante referência para vários teatrólogos e encenadores brasileiros, visto que o dramaturgo alemão propõe uma elaboração cênica desautomatizante por meio de

[...] processos narrativos, que ultrapassam o diálogo, e através da montagem livre de quadros e cenas sem encadeamento rigoroso - tudo isso para apreender e interpretar, de um modo crítico e didático, no reduzido espaço do palco, aspectos mais vastos e intrincados do mundo moderno (ROSENFELD, 2018a, p. 44).

O teatro épico, fundamentado em bases científico-sociológicas, reflete sobre a “"infraestrutura' social das ações em sua alienação coisificada" (SZONDI, 2015, p. 117). Considerando, pois, que a forma dramática se apoia na relação inter-humana e que os conflitos que dela emergem formam a temática do drama, no teatro épico, "ao contrário, é essa relação como um todo que passa a ser tematizada, como que transposta da inquestionabilidade da forma para o plano questionável do conteúdo" (SZONDI, 2015, p. 120).

Desse modo, pode-se identificar marcas do teatro épico na cena souziana. Na esteira de Brecht, Márcio Souza acena para a importância de não apenas entreter, mas também desautomatizar a plateia, trazendo à ribalta o discurso interdito pelo sistema dominante, visto que "O teatro épico questiona o caráter de diversão atribuído ao teatro. Abala sua validade social ao privá-lo de sua função na ordem capitalista. E ameaça a crítica em seus privilégios" (BENJAMIN, 2008, p. 86). Segundo seu idealizador:

Este tipo de teatro pressupõe, além de um determinado nível técnico, um poderoso movimento na vida social, movimento este não só interessado na livre discussão das questões vitais, visando à sua solução e dispondo da possibilidade de defender esse interesse contra todas as tendências que se lhe oponham (BRECHT, 2005, p. 74).

O dramaturgo amazonense põe em xeque o ilusionismo do drama convencional no intuito de levar o público a refletir acerca de sua própria realidade. Ressalte-se, todavia, que a obra dramática de Souza não é um mero decalque da teoria brechetiana. A exemplo de outros dramaturgos, Dias Gomes, por exemplo, o amazonense utiliza elementos do teatro épico quando estes lhe são interessantes, não como um receituário, sendo um ponto comum o empenho na conscientização da plateia e na contestação do status quo. Na base da dramaturgia de filiação brechetiana, reside a convicção de desmistificar a realidade, revelando que "as desgraças do 


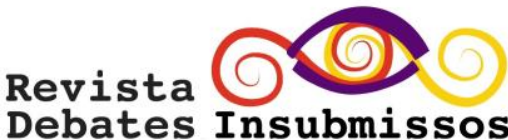

homem não são eternas e sim históricas, podendo por isso ser superadas" (ROSENFELD, 2018b, p. 150).

Nessa complexa conjuntura, a dramaturgia souziana, aliando modernidade, regionalismo e poesia, explora diversas formas dramáticas que venham ao encontro de seus interesses. Dentre essas, encontram-se tragédia grega, musical, teatro de revista, vaudeville, farsa, sátira social e política, teatro do absurdo e thriller policial. Essa heterogeneidade cênica propõe denunciar, polemizar, ridicularizar e desconstruir o discurso unitário do poder. Em outros termos, a palavra como arma de combate, o palco como espaço do grito, da luta, da dor e do brado retumbante de um povo esquecido. Daí ser, também, um teatro de resistência.

Dando continuidade ao artigo, a próxima seção pontua o início da carreira de Márcio Souza como cineasta, destacando a repercussão dessa experiência para sua literatura. Nesse bloco, mostra-se o encontro do escritor com o teatro a partir da aproximação, em Manaus, com o Teatro Experimental do Sesc. Assim, as principais marcas do teatro souziano são apresentadas, bem como a política teatral do grupo em revisitar, criticamente, a história amazônica, promovendo o resgate cultural da região. Vê-se, ainda, as contingências de produção de sua obra sob a constante ameaça da censura durante o regime civil-militar brasileiro.

\section{DRAMA NA SELVA}

Em consonância com o intrincado tecido amazonense, a obra de Márcio Souza se espraia em várias direções, por isso o cinema, o teatro, o ensaio e a literatura são trilhas que perfazem sua escritura. Em entrevista aos "Cadernos de literatura brasileira", em edição que lhe é dedicada, o escritor confessa que seu projeto original era ser diretor de cinema, pois acreditava que a arte cinematográfica seria capaz de romper o distanciamento entre o Brasil e a Amazônia: "O cinema, afinal era comunicação de massa. Eis aí a razão, digamos, política, do meu interesse pelo cinema" (SOUZA, 2005, p. 27). Contudo, essa experiência fez com que ele percebesse 


\section{Revista \\ Debates Insubmissos}

que, de fato, "gostava mais de escrever do que de passar pela intensa carga emocional e de trabalho das quatro, cinco semanas de filmagens" (SOUZA, 2005, p. 27).

É curioso notar que o seu trabalho como roteirista da Servicine, uma produtora e distribuidora da famosa Boca do Lixo paulistana, durante a década de 1960, deu-lhe o manejo diário com a palavra, o que o leva a reconhecer: "Eu aprendi a ser escritor na Servicine" (SOUZA, 2005, p. 26). Desse modo, ele passa da escrita cinematográfica para o texto literário. Nesse campo, emerge sua obra dramática, a qual traz, numa linguagem precisa, característica que se estende a sua literatura como um todo, o lirismo, a ironia, o deboche, a dor e o senso crítico.

Nota-se, pois, que o ponto convergente de sua trajetória literária é o compromisso artístico-social com a realidade que o cerca. Cônscio de seu papel cidadão, Souza não abre mão de suas convicções ideológicas e literárias, na verdade, ele prefere se indispor com os poderosos a lhe fazer concessões. No entanto, o escritor manauara não supervaloriza o alcance político da arte sobre o público, mas, ao mesmo tempo, acredita que sempre há conquistas: "Por isso mesmo, eu me orgulho muito, no caso do teatro, de termos tido, no âmbito da cidade de Manaus, algumas influências decisivas" (SOUZA, 2005, p. 30).

A produção teatral de Márcio Souza está diretamente ligada ao TESC - Teatro Experimental do Sesc -, grupo manauense no qual ingressou no início dos anos 1970 ao retornar de uma viagem à Europa. Na ocasião, o escritor, que morava na capital paulista desde 1965, pretendia residir novamente em sua terra natal, pois além de cansado da agitação da metrópole, a perseguição política cerceava as oportunidades de emprego. Em suas palavras: "A minha última prisão, pelo DOI-CODI, praticamente me impedia de trabalhar em São Paulo" (SOUZA, 1984, p. 25).

Seu primeiro projeto no TESC foi a direção do espetáculo "Espinhos no coração" (1973) que "não era uma peça de teatro, era um concerto de músicas e poesias, com alguns atores do grupo e músicos ligados ao TESC. Não passava de um show mas foi o suficiente para fazer-me provar do maravilhoso prazer que é ser de teatro" (SOUZA, 1984, p. 26). Segundo ele, esse retorno a Manaus era uma maneira de aprofundar o contato com a região, pois a realização do 


\section{nowite

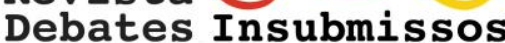

longa "A selva" (1972), adaptação do romance homônimo de Ferreira de Castro, deu-lhe a sensação de alheamento de suas raízes, conforme confessa em "O palco verde" " "Mas ao realizar o filme, senti-me um estrangeiro. Acabou por ser um filme distante, frio, ineficiente, onde a realidade da Amazônia estava de fora" (SOUZA, 1984, p. 25).

A experiência teatral de quase dez anos no TESC propiciou a imersão na cultura local. Era o que faltava para que aflorasse de vez o sentimento de pertencimento que o filme não lograra fazer, pois, nas palavras do dramaturgo, "Além de tudo, o teatro poderia ser o caminho para o meu encontro com a região amazônica, uma questão que me intrigava. Através do teatro eu imaginava poder encontrar as respostas que a região levantava e parecia instigar-me" (SOUZA, 1984, p. 26). Isso realmente se deu conforme mostra sua obra a partir dos anos 1970, não somente o teatro, também a romanesca, cujo marco inicial é "Galvez, imperador do Acre" (1976).

A parceria com o TESC proporcionou a criação de um teatro que não olhava com deslumbres exóticos ou fetichistas a realidade amazonense. A ideia do grupo era evitar o estigma de teatro folclórico ou regionalista, não por rejeição à cor local, mas para evitar a impressão de se tratar de uma novidade alienígena que, não raras vezes, acompanha o fazer artístico deslocado do eixo Rio-São Paulo. A respeito disso, o teatrólogo é incisivo:

Percebemos, por exemplo, que não podíamos cair na armadilha de repetir o regionalismo nordestino, requentando-o com uma nova embalagem. Ao examinarmos o processo amazônico, sentimos também a necessidade de escapar da tradição regionalista conforme os nordestinos tinham estabelecido, porque se tratava de uma forma de arte ainda inscrita dentro da manipulação ideológica da classe dominante daquela região. $\mathrm{O}$ regionalismo aparecia com um sabor muito conservador, e não queríamos mais trabalhar com aparências, ao contrário, nossa vontade era mergulhar nas culturas indígenas e na história da Amazônia, devolvendo ao público, no palco, de uma maneira crítica e liberta, aquilo que havia sido mistificado (SOUZA, 1984, p. 28-29).

A parceria com o TESC levou o escritor a revisitar o passado amazonense no intuito de compreender e problematizar o presente. Paralelo a isso, seu teatro encena os relatos míticos indígenas e traz à baila os mecanismos de dominação, a ganância capitalista, os caminhos tortuosos da política, o esmagamento das populações nativas, como também a exploração dos

4 Ensaio analítico-memorialístico no qual Márcio Souza relata e comenta sua experiência teatral junto ao TESC. 


\section{Revista \\ Debates Insubmissos}

trabalhadores. Segundo o teatrólogo: "A proposta original do TESC era correr principalmente num par de trilhos: um voltado para uma visão crítica do processo histórico da Amazônia e outro dedicado às culturas originárias dos povos indígenas" (SOUZA, 2005, p. 31). Na sequência, ele acrescenta: “Às vezes, além de aproximarmos os dois campos, enfatizamos uma outra característica que estava presente na primeira fase do grupo: o trabalho com grandes textos do teatro mundial" (SOUZA, 2005, p. 31).

Todo esse empenho em defesa de um teatro crítico e participativo levou Márcio Souza e seu grupo a revirar o baú da história e tirar de lá os ossos da barbárie colonial. Em vez do emudecimento dos povos nativos, sua concepção mítica de mundo veio à cena. No lugar do aviltamento de figuras do passado amazonense, em especial, as indígenas, sua exaltação no palco. Em substituição à historiografia oficial, a versão das classes excluídas ganhou a ribalta. À luz da arte, esse propósito implicava um contraponto ao discurso hegemônico. Em suma, um teatro com largo efeito desautomatizante:

Se para o TESC a cultura amazônica significava a resistência dos povos indígenas e as lutas dos trabalhadores, não era exatamente isto o que a tradição informava. Mas a insistência do grupo deixaria marcas profundas e o teatro nunca mais seria o mesmo em Manaus. Para o TESC a cultura amazônica autêntica sempre foi aquela expressada pelas forças populares em suas lutas, verdadeiro rio subterrâneo que deu à Amazônia, ao longo da História, unidade e estatura moral. Por isto nunca fomos complacentes com o exótico e sempre procuramos manifestar o nosso horror pelo folclórico (SOUZA, 1984, p. 67).

Entretanto, o caminho não foi nada fácil. A produção teatral de Souza veio à luz sob o jugo da ditadura militar. Com a vigência, desde 1968, do AI-5 (Ato Institucional $\mathrm{n}^{\mathrm{o}}$ 5), a sociedade vê tolhida toda e qualquer forma de liberdade de expressão - política, artística e civil - em vista dos interesses estatais. Nesse terrível cenário, os artistas, para não falar de todos os casos de perseguição, são postos sob constante suspeita, o que resulta, não raras vezes, em cortes e interdição de suas obras. Rodrigues (2018, p. 64) retrata o cenário artístico de resistência durante a ditadura militar brasileira, dizendo que "As artes literárias, cinematográficas, musicais, performáticas, entre outras, foram motores de questionamento da ditadura militar, colocando-se enquanto movimentos de resistência, e produziram importantes obras." 
$\mathrm{Na}$ extensa lista de censura teatral do período, figuram, além de Márcio Souza, por exemplo, Chico Buarque, Nelson Rodrigues e Dias Gomes. Considerando, pois, o pensamento de Hannah Arendt a respeito do funcionamento dos sistemas opressores, vale mostrar que:

\begin{abstract}
Nas condições do regime totalitário, a categoria dos suspeitos compreende toda a população; todo pensamento que se desvia da linha oficialmente prescrita e permanentemente mutável já é suspeito, não importa o campo de atividade humana em que ocorra (ARENDT, 2018, p. 571).
\end{abstract}

Os regimes totalitários mobilizam um engenhoso aparato repressor contra qualquer ideia contradiscursiva ou atitude considerada subversiva. Em vista disso, Arendt (2018, p. 571) esclarece que "Simplesmente em virtude da sua capacidade de pensar, os seres humanos são suspeitos por definição, e essa suspeita não pode ser evitada pela conduta exemplar, pois a capacidade humana de pensar é também a capacidade de mudar de ideia." Essa realidade apresentada pela filósofa alemã é o que se verifica no Brasil nos anos de chumbo da ditadura militar (1964-1985).

Nesse cenário de silenciamento, a primeira peça de Márcio Souza esbarrou na tesoura anômala da censura. Escrita em 1968, “Zona Franca, meu amor”, conforme indica o título, põe em evidência a investida econômica do governo federal no coração da selva amazônica. Coerente com o ideário do autor e do TESC, a peça consiste numa crítica contundente à exploração capitalista da região. No quadro de sombras e mordaças no qual o país mergulhara, o resultado não poderia ser outro. Em fevereiro de 1974, uma semana antes da estreia, o texto estava proibido em todo o país. Somente em 1978, sob o empenho de Ruth Escobar, que pretendia encenar a peça, o texto foi liberado com o sugestivo título de "Tem piranha no pirarucu".

Apesar do clima de suspeita e de vigilância durante o regime ditatorial, o teatro souziano nunca abriu mão de levar ao palco o descontentamento com as (des)ordens vigentes, revelandose como um teatro de resistência crítica. Ressalve-se, todavia, que o alcance de sua dramaturgia vai além das contingências históricas, pois sua matéria criativa - temas e linguagem - revestese de uma pulsante problematização acerca do ser humano e da ideologia dominante, seja ontem, hoje ou amanhã. Em vista disso, o dramaturgo declara: "No mais, esperamos que nosso 
teatro continue estimulando aos nossos companheiros de lutas, irritante aos oportunistas e pouco palatável aos exploradores. E que seja uma festa para o nosso público” (SOUZA, 1982, p. 91).

Assim, a próxima seção tece um painel das peças de Márcio Souza, destacando suas principais linhas temáticas, as quais formam uma teia criativa onde o diálogo e as imbricações são constantes. A cronologia de escrita e de representação das obras são postas em suspenso, tendo em vista que a aproximação temática não coincide com a ordem temporal de seu surgimento.

\section{PALCO MULTICOR}

O teatro de Márcio Souza focaliza a realidade amazônica mediante múltiplos olhares, mas sem abandonar as raízes regionais e nem cair na armadilha do pitoresco. A esse respeito, o autor comenta: "Mas nunca permitimos que a absolutização da problemática regional obscurecesse nossa compreensão dos fenômenos sociais em seu nível mais geral" (SOUZA, 1984, p. 67-68). Isso só foi possível graças ao "contínuo estudo, pesquisa, conhecimento cada vez mais aprofundado da ciência histórica e a investigação do fenômeno da luta de classes em suas diversas manifestações, tanto locais quanto internacionais" (SOUZA, 1984, p. 68). Essa metodologia de trabalho crítico-criativo permitiu que sua escritura dramática se desenvolvesse a contento, apesar das adversidades que o TESC e o próprio escritor tiveram que enfrentar.

Circunscrito ao aspecto literário, o presente estudo não se atém às encenações das peças, embora não esqueça sua potencialidade espetacular. Tendo em mira uma organização didática, as mesmas são apresentadas, nesta seção, segundo a perspectiva espacial. Não obstante as diferentes configurações estruturais e temáticas, salta aos olhos que, das onze peças, apenas duas não tenham a Amazônia como cenário, o que justifica dividi-las em peças "amazônicas" e "não-amazônicas".

As peças amazônicas têm como núcleos temáticos a história, a mitologia indígena, a economia e a política, mas sem exaurir-se no regionalismo, no folclórico ou no exótico. Pelo 


\section{Revista \\ Debates Insubmissos}

contrário, os temas são tratados com muita agudeza, mostrando sua ligação com a realidade brasileira, não os isolando na selva. Compõem o conjunto "A paixão de Ajuricaba" (conhecida como "Ajuricaba", 1974), "Dessana, Dessana" ou "O começo antes do começo" ("Dessana", 1975), "Jurupari, a guerra dos sexos” (“Jurupari”, 1979), “A maravilhosa história do sapo TarôBequê" ("Tarô-Bequê", 1975), "Contatos amazônicos de terceiro grau" ("Contatos", 1978), "Pequeno teatro da felicidade" ("Pequeno teatro", 1977), "As folias do látex" (“As folias", 1976), "Tem piranha no pirarucu" (“Tem piranha", 1978) e "A resistível ascensão do Boto Tucuxi" ("Boto Tucuxi”, 1982). O segundo grupo inclui as peças "O elogio da preguiça" ("O elogio”, 1980) e “Ação entre amigos” (“Ação”, 1987)5.

Dentre as peças amazônicas, a maior parte elege a cultura indígena como principal foco, é o caso de "Ajuricaba", "Dessana", "Jurupari”, "Tarô-Bequê" e "Contatos". Longe de formar blocos homogêneos, esse conjunto espelha a diversidade cultural da região, conforme garante Souza (2005, p. 47): “Temos diversas Amazônias. O que vale para o sul da Amazônia não vale para a região dos grandes rios, a região montanhosa. A Amazônia é um subcontinente de muitos contrastes." Centradas na cultura autóctone, essas obras têm o mito, a história e a sociocrítica como fios condutores.

A mitologia indígena é a base das peças "Dessana", "Jurupari” e "Tarô-Bequê". Transitando entre a ópera e o musical, "Dessana", escrita em parceria com o poeta Aldísio Filgueiras e musicada por Adelson Oliveira, encena a cosmogonia segundo a visão dessana, povo de ramificação aruaque do alto Rio Negro. Ao mesmo tempo que mostra a riqueza mítica desses povos, a peça denuncia a marginalização do indígena nos caos urbano de Manaus. $\mathrm{O}$ mito, nesse caso, funciona como uma janela através da qual é possível ver o esmagamento da cultura nativa frente à colonização ao passo que a fabulação mitológica propõe a perenidade dos povos guardiões dessas narrativas.

\footnotetext{
5 Visando a dinamizar a leitura, sempre que oportuno, as peças serão referidas pelas formas abreviadas indicadas nos parênteses. As datas que acompanham as mesmas assinalam o ano de escrita das peças, o que, na maior parte dos casos, coincide com a data de sua primeira encenação.
} 


\section{Revista \\ Debates Insubmissos}

"Jurupari”, por sua vez, trata do herói mítico civilizador, promotor de leis e costumes, identificadores culturais dessas populações. Mesclando poeticidade e erotismo, a obra mostra faces do ritual instituído por Jurupari, bem como a tensão entre patriarcado e matriarcado. Envolvo num clima de tragicidade, o mito surge na peça como fator identitário dos povos nativos, uma forma de permanência apesar das intromissões do homem branco. Conforme pontua Rosenfeld (2018a, p. 26), "O mito salienta a identidade essencial do homem em todos os tempos e lugares.” Desse modo, a sacralidade indígena toma corpo no palco souziano, estratégia para desprogramar o olhar burguês acostumado às peripécias cênicas de sua própria classe.

Por fìm, "Tarô-Bequê", concebida como comédia moral para crianças, apresenta as façanhas do protagonista cujo maior desejo é tornar-se um ser humano, o que termina gerando um percurso trágico para o herói. Paralelo a isso, o dramaturgo provoca o riso ao misturar dados da cultura nativa com elementos exógenos, aproveitando o ensejo para criticar a exploração estrangeira. A peça aborda ainda o inconformismo humano diante do estabelecido, dando relevo às consequências negativas advindas da ousadia de ultrapassar os limites impostos. $\mathrm{O}$ sapo Tarô-Bequê é punido por sua desmedida, contudo a retomada cíclica do mito mostra que, para além da exemplaridade da narrativa, o sonho do protagonista não se rompe de todo, a palavra mítica o recupera sempre e indefinidamente.

Ao contrário das outras peças de temática indígena, "Ajuricaba" não parte do componente mítico, mas histórico. Estruturada aos moldes da tragédia grega, a peça traz ao palco a história do chefe manau que comandou a resistência nativa aos portugueses no séc. XVIII. Com essa obra, Márcio Souza subverte a historiografia oficial ao propor outra versão para o episódio, inclusive em relação ao destino do herói. Em vez do suicídio, conforme o discurso canônico, Ajuricaba é vítima de uma trama assassina engendrada pelos colonizadores. Além disso, a peça alça o protagonista ao patamar mítico, segundo se observa no desfecho anunciado na rubrica cênica: "Os soldados jogam Ajuricaba no rio e o herói é recebido nos braços das três entidades míticas que o levam para a eternidade” (SOUZA, 1997a, p. 45). 


\section{Revista \\ Debates Insubmissos}

A peça não apenas trazia outra versão da história oficial, mas também tocava na ferida exposta do regime ditatorial, denunciando a violência e o silenciamento dos que a ele se opunham. A esse respeito, declara Souza (1984, p. 30): “A tragédia de Ajuricaba vinha para o patético daqueles dias escuros, de prisioneiros políticos e desaparecidos, de torturados e mortos, o que tocava num sensível ponto do público.” Na verdade, o drama lírico-épico de Ajuricaba constitui um libelo contra toda e qualquer forma de opressão e estado de injustiças, sejam passadas ou presentes.

Por seu turno, "Contatos" ${ }^{6}$, peça curta de um só ato, apresenta o casal protagonista Catuauá e Nudá - frente a um mundo desconhecido, tecnológico, externo. O gravador deixado na mata pelo homem branco e os tratores são percebidos segundo sua visão mítico-cultural, o que os impede de compreender seu real significado. Trata-se, de fato, de metáforas dramáticas da destruição perpetrada pelos invasores coloniais e pelas empreitadas capitalistas. Desse modo, é significativo que, ao final da peça, o gravador toque o Réquiem, de Mozart, prenúncio de morte, enquanto o barulho dos tratores anuncia a devastação da floresta. Ecologia, arte e denúncia se aliam nesses perigosos contatos de mundos díspares. Partindo da ótica indígena, a peça inverte a forma de perceber o outro, o homem branco é visto como, potencialmente, ameaçador, emissário de morticínios que deve ser evitado, bem diferente da tradicional visão idílica sustentada pelos colonizadores quando da invasão das terras brasileiras.

Fora do âmbito indianista, as outras peças amazônicas apresentam-se como sátiras aos modelos econômicos, aos desmandos políticos, à exploração dos recursos naturais e à submissão de indígenas e trabalhadores. Centrada no ciclo da borracha, "As folias do látex", subintitulada de vaudeville ${ }^{7}$, é uma crítica corrosiva aos exploradores do universo extrativista e às duras consequências para a população nativa. Segundo Del Rios (1997, p. 13-14), "Toda a obra é superlativa na comicidade contrastada com dados econômicos mundiais, episódios da

\footnotetext{
${ }^{6}$ Ao lado de outras nove, essa peça integra o projeto idealizado por Ruth Escobar intitulado Feira Brasileira de Opinião. Escritas especialmente para o projeto, as peças não puderam ser encenadas porque foram censuradas pela ditadura militar.

${ }^{7}$ Teatro de variedades, com forte apelo popular, envolvendo música, dança e performances cômicas.
} 


\section{Revista \\ Debates Insubmissos}

história e flashes doloridos da farsa provinciana onde fome, coronelismo, rapinagem bancária, míseras festas de bordel formam uma realidade pesada."

"As folias" é uma espécie de revista musical na qual o deboche e a ironia não estão ausentes, muito pelo contrário, constituem sua carga dramática. Apesar da enorme circulação monetária, responsável pela ascensão dos coronéis da borracha na chamada belle époque amazônica, o resultado foi o empobrecimento e a exclusão daqueles que já eram miseráveis. Em meio a uma enxurrada de informações históricas, econômicas e culturais feitas por meio de projeções, a peça denuncia os absurdos da colonização, o enriquecimento das elites e o estado de penúria a que são levados trabalhadores e indígenas. $\mathrm{O}$ clima cômico da peça não apaga de todo o rancor contra tanta exploração. Em suma, as folias foram, e ainda são, proveitosas para o bloco elitista e desastrosas para os demais.

Ao passo que "As folias" focaliza o ciclo da borracha, "Tem piranha no pirarucu" imerge no cenário da Zona Franca de Manaus. Conforme o autor, a peça é "a comédia das impossibilidades da mentalidade extrativista amazonense libertar-se das ilusões e compreender o fenômeno da Zona Franca" (SOUZA, 1984, p. 55). Entre risos, música e escracho, a obra encerra uma crítica ácida aos disparates econômicos, uma verdadeira zona de negociatas e picaretagens em nada inédita na história brasileira. Como "As folias", também uma revista musical, ao fundo amarga, reveladora das lágrimas das vítimas dessa zorra capitalista mascarada pelo riso dos endinheirados.

Sem pudores, as personagens de "Tem piranha" exaltam a desfaçatez da nação em entregar aos exploradores estrangeiros o mercado brasileiro. Na peça, a Zona Franca não é tão franca assim, pelo contrário, é o local nebuloso do lucro e da negociata. Da mesma forma, Manaus é uma zona de prostituição capitalista, onde as piranhas e outros tubarões da economia tentam abocanhar o máximo de lucro.

Com a ação situada na Manaus do ano de 1836, "Pequeno teatro da felicidade" mescla elementos históricos, fantasia, aventura, crimes e perseguição política. A referência histórica abarca o contexto da Cabanagem (1835-1840), revolta popular violentamente abafada pelo governo imperial. Logo se percebe que o pano de fundo histórico não é o interesse central do 


\section{Revista \\ Debates Insubmissos}

dramaturgo, a peça não pretende falar, exclusivamente, da Revolta dos Cabanos, esta funciona mais como um mote para outras discussões.

O que prepondera no "Pequeno teatro" é o clima de animosidade, perseguição e tortura aos considerados subversivos ao regime vigente, qualquer semelhança com o período ditatorial não é mera coincidência. Nas palavras de seu autor, a peça é um misto de "fantasia e pesadelo político, que reconstruía um clima sombrio não muito distante daqueles anos de fechadura completa" (SOUZA, 1984, p. 48). Não obstante a marcação temporal, a peça é uma denúncia contra todo e qualquer governo totalitário, seja dantes ou de agora.

Outro dado importante no "Pequeno teatro" é a utilização do metateatro, representado por uma trupe de atores ambulantes. Com esse artifício, a ação dramática é apresentada como um espetáculo de rua, popular, à moda do teatro medieval itinerante, a influência da Commedia Dell'Arte é nítida. No meio da trama política, os saltimbancos, apoiados pelo sapateiro Pedro, denunciam o estupro e a morte de uma jovem pelo filho do comandante local. Disso resulta a prisão e o julgamento do grupo, mas também a tortura e o desaparecimento (morte?) de Pedro. Para sobreviver, os artistas negam o testemunho. Com esse jogo cênico, a verdade é mostrada e, ao mesmo tempo, mascarada; o riso finge esconder a lágrima, a arte denuncia e nega, apontando para a crueza da realidade. Num país onde a justiça não prevalece, o "Pequeno teatro da felicidade" traz ironia no título e no enredo, talvez melhor seria chamar-se o grande teatro da infelicidade e da amargura.

Conclui o grupo das peças amazônicas “A resistível ascensão do Boto Tucuxi”, um vaudeville cujo título inspira-se em Brecht ${ }^{8}$. Crítica mordaz à política brasileira dos anos de repressão, a obra foi encenada no Teatro Amazonas devido ao fechamento do teatro do TESC dois anos antes pela direção do Sesc. Este foi o último trabalho do grupo antes de sua retomada em 2003. Acerca do contexto político de surgimento da peça, Souza (1984, p. 66) informa: “A peça, que falava de corrupção, tráfico de narcóticos e política, chegava no instante em que presenciávamos a ressurreição do cadáver mumificado do populismo."

\footnotetext{
8 “A resistível ascensão de Arturo Ui” (1941).
} 


\section{Revista \\ Debates Insubmissos}

Cínico, lúbrico, manipulador e hedonista, o protagonista, vaticinado por bruxas decrépitas, numa versão cômica de Macbeth, passa de traficante a governador do Amazonas. O Boto, segundo seu criador, “é a projeção de todos nós, coniventes em nossa pasmaceira e capazes de outorgar mandatos ao primeiro que aparecer sorrindo em nossa frente, prometendo mundos e fundos e lubrificando nossa inconsciência com esmolinhas pré-eleitorais" (SOUZA, 1984, p. 66). É a velha e não menos atual política brasileira do toma lá dá cá. Pelo visto, o país insiste em não aprender a lição.

O Boto Tucuxi é a imagem da camaleônica classe dominante sempre moldando-se aos tempos e lugares para nunca desocupar a cadeira de mando, não medindo esforços nem meios para isso. Discurso demagógico, clientelismo, suborno, fraude, corrupção sistemática, uso da máquina estatal, chantagem, violência e assassinatos - a lista não é curta - são alguns itens do receituário da pior política brasileira que a peça de Souza expõe. Infelizmente, um quadro que a atualidade não deixa de reiterar.

No outro extremo, as peças não-amazônicas, centradas no Rio de Janeiro, têm como tema principal as marcas indeléveis do regime ditatorial na sociedade brasileira. $\mathrm{O}$ tratamento político dessas obras manifesta-se num clima farsesco e mesmo absurdo, caso de "O elogio da preguiça”, e de thriller policial em “Ação entre amigos”. Sobre essas peças, Hardman (2005, p. 107) considera que "o autor parece acertar a mão, produzindo textos ao mesmo tempo contundentes e ágeis em seu humor agudo."

O período de encenação de "O elogio" coincide com o fechamento do teatro do TESC, sede do grupo. É verdade que este tinha alguns problemas internos, mas o fator decisivo para o trancamento das portas foi a crescente tensão entre os membros do grupo e a direção da entidade, pressionada pela elite local que, cada vez mais, sentia-se incomodada com o constante teor crítico das peças. Acerca desse episódio, Márcio Souza desabafa:

O que mais doeu, para todos nós, não foi o ato arbitrário da direção do Sesc. Na situação em que as relações do grupo com a instituição se encontravam, era de se esperar uma atitude dessa natureza. Mas o silêncio de toda a cidade, dos órgãos de imprensa, dos intelectuais, dos artistas, como se nada tivesse acontecido, isto nos feriu muito. Para completar o quadro absurdo, uma boa parte da chamada classe teatral comemorou a nossa desgraça (SOUZA, 1984, p. 64). 


\section{Revista \\ Debates Insubmissos}

"O elogio" põe em cena uma embaixatriz de uma tradicional família na política, sua empregada que ela chama de afilhada, um general e um homem misterioso. Crítica corrosiva aos modelos políticos, em especial, à ditadura militar, a peça debocha e ridiculariza as artimanhas da elite no comando da nação. O dramaturgo não dispensa ninguém, por isso é sintomática a generalizante fala final quando se diz: "Não valemos um pentelho do cu" (SOUZA, 1997b, p. 114). Mais uma vez o riso, o deboche, o baixo calão e a ironia mostram a realidade absurda do país onde a minoria rica lamenta a perda de privilégios obtidos com a opressão estatal. Para os abastados, não importa a liberdade de expressão, mas sim os ganhos que a situação pode lhes garantir.

Nessa peça, o coração reacionário do país lamenta a perda de privilégios no ocaso do regime militar, contudo não se trata do fim dessa política do horror, os seus partidários sabem se acomodar e tirar proveito das novas ondas governistas. Enquanto não podem vir à luz plenamente, eles aguardam, pois a intolerância e a sombra dos regimes de mando não se cansam de rondar o Brasil e ressurgem sempre que oportuno, como está se vendo atualmente. O humor de Souza é uma chicotada no riso, uma gargalhada com efeito de lágrima. Uma das falas de Melusine, a embaixatriz, é sintomática do cinismo elitista: “A vida é uma loucura. Quem não se conforma, vai para o hospício. Alguns são fuzilados, ou encarcerados, ou torturados. E assim é melhor" (SOUZA, 1997b, p. 112). É desnecessário dizer para quem é melhor este estado de coisas.

Por fim, "Ação entre amigos"9 , peça criminal em três atos conforme anuncia o subtítulo, traz um clima de suspense policial numa casa de veraneio em Itatiaia $(\mathrm{RJ})$ num fim de semana chuvoso. Em meio a uma série de assassinatos brutais, as personagens, a maioria relacionada ao campo militar e à política, exasperam os nervos com telefonemas ameaçadores, sonhos nazistas e memórias da violência do período ditatorial. Presas e isoladas na casa, as personagens são confrontadas com sua ligação com o crime e a repressão. Com isso, vem à tona a corrupção, as negociatas e a brutalidade, bastidores da política nacional durante o regime de exceção, mas

\footnotetext{
${ }^{9}$ Encenada, pela primeira vez, no Teatro Ipanema, no Rio de Janeiro, com direção de Paulo Betti (cf. CADERNOS DE LITERATURA BRASILEIRA, 2005, p. 170).
} 


\section{Revista \\ Debates Insubmissos}

não exclusivo dele. Mais uma vez, Márcio Souza bate na mesma tecla: o poder não se envergonha dos meios que usa para sua manutenção e seus agentes, qual vendilhões do templo, negociam, indiferentemente, com Deus e com o Diabo.

A trama policial é o mote que o dramaturgo utiliza para discutir os escorregões da política brasileira. Um dos protagonistas, o General Luís Moreira, afirma no Primeiro Ato: "O Brasil é um país infeliz, Leni” (SOUZA, 1997b, p. 123), ao que a esposa responde: "Eu não acho. Isto aqui é na verdade um país de cínicos. Ninguém acredita em nada, não se leva nada a sério, só querem é se arrumar e o resto que se dane. Papai costumava dizer que nem os ciganos são tão amorais quanto os brasileiros" (SOUZA, 1997b, p. 123). Assim, ao longo do texto, Souza solta suas farpas em todas as direções possíveis, fazendo uma radiografia dos desmandos nacionais, entre os quais não faltam os traumas do período ditatorial, as negociatas, os sequestros, os estupros, a tortura e os grupos de extermínio. A esse respeito, a fala de Marlene, a empregada da casa, é reveladora: "Atualmente a melhor diversão da polícia é achar cadáveres, corpos em decomposição e ossadas, especialmente ossadas... Os tiras deliram! [...] A nossa arqueologia acabou virando perícia criminal" (SOUZA, 1997b, p. 198). A “Ação entre amigos" de que fala o título remete ao conluio dos que não medem esforços para se manter no poder.

Diante do exposto, vê-se que, mesmo olhando de perto o solo natal, o teatro de Márcio Souza apresenta uma visão mais abrangente acerca da realidade, o que o impede de circunscrever as questões da Amazônia aos limites de seu próprio território. Em vista disso, ele explica a forma como encara a situação: "Eu acho que não existe um 'problema da Amazônia'. O que há é um 'problema nacional': não se consegue estabelecer uma estratégia integral para o país, um projeto de nação. Sem isso, você não possui nada, nem uma região" (SOUZA, 2005, p. 46). Nessa perspectiva, ele completa o pensamento nos seguintes termos: "Se você aceita que exista um 'problema na Amazônia', tem de admitir um 'problema do Sudeste', um 'problema do Sul' e assim por diante" (SOUZA, 2005, p. 46-47).

Nesse sentido, é válido o pensamento de Machado de Assis quando evidencia, em torno da temática do nacionalismo literário, a importância dos escritores manterem ligações com sua terra, mas sem deixar escapar a macroestrutura: "Não há dúvida que uma literatura, sobretudo 
uma literatura nascente, deve principalmente alimentar-se dos assuntos que lhe oferece a sua região; mas não estabeleçamos doutrinas tão absolutas que a empobreçam" (ASSIS, 2019, p. 3). Com isso, o criador de Brás Cubas propõe dois olhares, simultâneos e complementares, um voltado à cor local, outro para além dos próprios muros. Lição que Souza não deixa de seguir, o que termina dando vigor e dinamismo a sua obra.

Assim, o próximo tópico encerra a proposição deste trabalho em apresentar os aspectos gerais do teatro de Márcio Souza, tendo em vista o conhecimento, a leitura e o debate acerca de sua dramaturgia. São apontamentos finais, mas não definitivos, de uma trajetória crítica que acreditamos frutífera e duradoura.

\section{ANTES DA CORTINA SE FECHAR (OU NOSSOS ÚLTIMOS APONTAMENTOS)}

Uma das premissas da obra de Márcio Souza reside na convicção de que produzir arte é posicionar-se criticamente. $\mathrm{O}$ escritor entende que não há inocência nem isenção nesse campo, por isso o artista não pode se anular, criar é colocar-se frente ao mundo, a si mesmo e ao outro. Sob esse ângulo da questão, sua dramaturgia adere à tradição de importantes nomes da arte cênica mundial preocupados com as raízes populares do teatro. Segundo Rosenfeld (2018a, p. 43), "Nos grandes momentos do teatro - quase sem exceção momentos de teatro popular - os dramaturgos protestavam, reivindicavam e reafirmavam, ao nível da consciência da respectiva época, ideais e valores avançados.” Assim, por meio de sua arte, o autor manauara legitima seu direito ao grito e ao riso, mas sempre com uma pitada de inteligente resistência.

O teatro de base popular, sem abandonar a postura crítica, segundo defende Rosenfeld (2018a, p. 42), não deve se eximir de entreter o público "através da sátira, paródia, farsa, caricatura e de todos os recursos da ironia, do sarcasmo e da comicidade, sem dúvida eficazes na elucidação, através do desmascaramento e da desmitificação de tabus, convenções estéreis e mitos nocivos." 


\section{Revista \\ Debates Insubmissos}

Assim, é notável que a dramaturgia de Souza percorre, com eficiência, os diversos trilhos assinalados por Anatol Rosenfeld, pois é um teatro que diverte, pensa, emociona e não emudece diante das pressões, mas instiga ações, pensamentos e críticas.

O teatro souziano, sem perder as rédeas da criação poética, e mantendo-se fiel a seus propósitos ideológicos, configura-se na diversidade de formas dramáticas. Além do uso de recursos do teatro épico de Brecht, Souza dialoga e subverte a tradição teatral, o que permite sua incursão no drama, no vaudeville, no teatro de revista, na tragédia, no musical, na comédia moral, na farsa e na peça policial. O dramaturgo não se intimida diante das muitas variáveis que precisa laborar, pelo contrário, ele se lança com afinco em suas metas.

O esforço criativo de Souza resulta numa obra teatral multifacetada na qual tem lugar o riso, o deboche, a ironia, a denúncia, o choro, o canto, a poesia, o mistério e o mito. Ao mesmo tempo que olha além da fronteira regional, o seu teatro não pode deixar de lado a exuberante paisagem natural, os diferentes modos de vida e o convívio nem sempre harmonioso com seus conterrâneos.

Vê-se, pois, que o teatro souziano, de fundas raízes amazônicas, não se limita a olhar apenas a região, antes a insere numa discussão mais ampla em torno da arte, das novas expressões teatrais, dos posicionamentos ideológicos, da política e das problemáticas sociais. Em síntese, "o escritor realmente é mais político que regionalista (não lhe peçam jamais descrições realistas de vidas na beira do rio)” (DEL RIOS, 2005, p. 143). A dramaturgia de Souza é um rio de muitos afluentes.

Por fim, o teatro de Márcio Souza, antropofagicamente, digere tudo que venha contribuir para a construção de uma dramaturgia crítica, no centro da qual se reflete o mundo, a linguagem artística, as relações interpessoais e o nefasto percurso do poder, mas sem esquecer o ser humano em sua constante busca por liberdade e dignidade. Palco vibrante, ansioso de vida, politizado e belo.

O palco de Márcio Souza é povoado por heróis indígenas, figuras mitológicas do Alto Rio Negro, seres fantásticos do imaginário amazônico, mas também por coronéis da borracha, 
rufiões, militares empedernidos, políticos corruptos, negociantes cínicos, prostitutas, artistas, idealistas da causa popular, dentre outros. Inseridas nas mais diferentes formas dramáticas, suas criaturas executam o riso e a lágrima, mas sempre de olho na discussão em torno do país.

Vê-se, portanto, que a dramaturgia souziana oferece grandes possibilidades de análise, o que exige estudos particulares ou mais extensos das peças do amazonense, um desafio que se abre a quem deseje novas imersões nessa obra instigante.

\section{REFERÊNCIAS}

ARENDT, Hannah. O totalitarismo no poder. IN: ARENDT, Hannah. Origens do totalitarismo: antissemitismo, imperialismo, totalitarismo. Tradução de Roberto Raposo. 10. reimpres. São Paulo: Companhia das Letras, 2018. p. 528-610.

ASSIS, Machado de. Notícia da atual literatura brasileira: instinto de nacionalidade. Disponível em: http://www.letras.ufmg.br/padrao_cms/documentos/profs/sergioalcides/machadinstinto.pdf. Acesso em: 28 out. 2019.

BENJAMIN, Walter. Magia e técnica, arte e política: ensaios sobre literatura e história da cultura. Tradução de Sergio Paulo Rouanet. Prefácio de Jeanne Marie Gagnebin. 7. ed. [1994]. 11 reimpr. São Paulo: Brasiliense, 2008.

BOSI, Alfredo. Anchieta ou as flechas opostas do sagrado. IN: BOSI, Alfredo. Dialética da colonização. 4. ed. [2001], acrescida de posfácio. 8. reimpr. São Paulo: Companhia das Letras, 2010. p. 64-93.

BRECHT, Bertolt. Estudos sobre teatro. Tradução de Fiama Pais Brandão. Apresentação de Aderbal Freire-Filho. 2. ed. Rio de Janeiro: Nova Fronteira, 2005.

CADERNOS DE LITERATURA BRASILEIRA: Márcio Souza. São Paulo: Instituto Moreira Salles, n. 19, dez. 2005.

DEL RIOS, Jeferson. A paixão do palco verde. Prefácio. IN: SOUZA, Márcio. Teatro I. Textos revistos e estabelecidos pelo autor. São Paulo: Marco Zero, 1997.

DEL RIOS, Jeferson. Dentro do palco verde. IN: Cadernos de literatura brasileira: Márcio Souza. São Paulo: Instituto Moreira Salles, n. 19, p. 134-145, dez. 2005. 
HARDMAN, Francisco Foot. Revolta na planície do esquecimento: a grande falha amazônica. IN: Cadernos de literatura brasileira: Márcio Souza. São Paulo: Instituto Moreira Salles, n. 19, p. 96-117, dez. 2005.

PRADO, Décio de Almeida. O teatro brasileiro moderno. 3. ed. [2007]. 2. reimpre. São Paulo: Perspectiva, 2018. (Coleção Debates, 211).

RODRIGUES, Walace. Cinema brasileiro e erotismo durante a ditadura militar. Revista Porto das Letras. Universidade Federal do Tocantins - UFT, Porto Nacional, vol. 04, $\mathrm{N}^{\mathrm{o}} 03$, Edição Especial, 2018, pág. 61-71. Disponível em:

$<$ https://sistemas.uft.edu.br/periodicos/index.php/portodasletras/article/view/5860>. Acesso em: 02 mar. 2021.

ROSENFELD, Anatol. O mito e o herói no moderno teatro brasileiro. 2. ed. [2012]. 1. reimpres. São Paulo: Perspectiva, 2018a. (Coleção Debates, 179).

ROSENFELD, Anatol. O teatro épico. 6. ed. [2008]. 5. reimpres. São Paulo: Perspectiva, 2018b. (Coleção Debates, 193).

SOUZA, Márcio. A questão do teatro regional. IN: DIMAS, Antonio (org.). Márcio Souza. São Paulo: Abril Educação, 1982. p. 86-91. (Coleção Literatura Comentada).

SOUZA, Márcio. Entrevista: ofício de escritor. IN: Cadernos de literatura brasileira: Márcio Souza. São Paulo: Instituto Moreira Salles, n. 19, p. 22-49, dez. 2005.

SOUZA, Márcio. O palco verde. São Paulo: Marco Zero, 1984.

SOUZA, Márcio. Teatro I. Textos revistos e estabelecidos pelo autor. São Paulo: Marco Zero, 1997a.

SOUZA, Márcio. Teatro III. Textos revistos e estabelecidos pelo autor. São Paulo: Marco Zero, 1997b.

SZONDI, Peter. Teoria do drama moderno (1880-1950). Tradução e notas de Raquel Imanishi Rodrigues. Apresentação de José Antônio Pasta Jr. 2. ed. [2011]. 1. reimpres. São Paulo: Cosac Naify, 2015.

Submetido: $02 / 03 / 2021$

Aprovado: 12/04/2021 